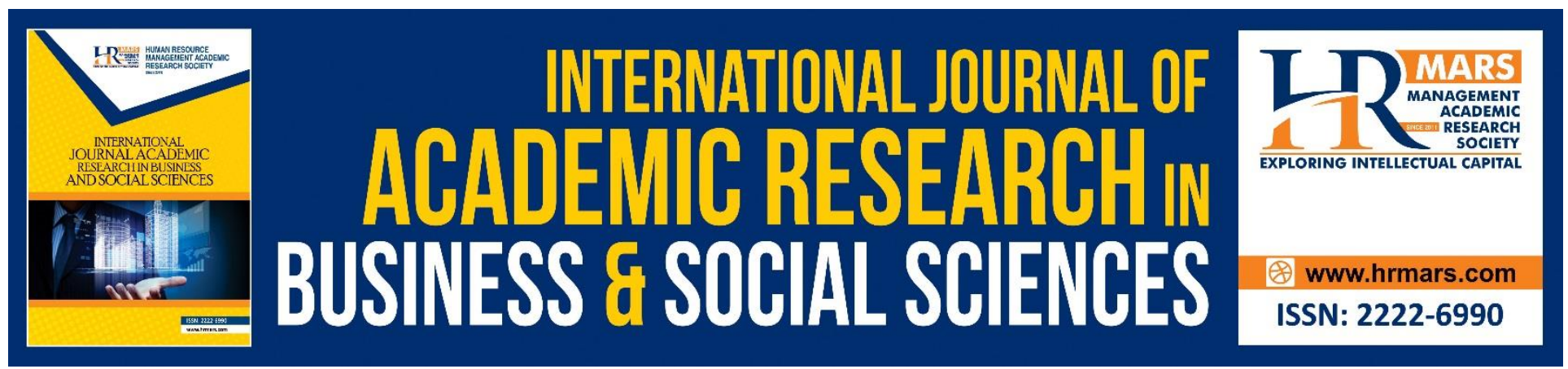

\title{
Strategies to Improve Performance Adopted by Social Enterprises in Kenya
}

\author{
Karanja Ann Wangui, Odero Auma Faith, Ng 'ong 'a E. Aketch
}

To Link this Article: http://dx.doi.org/10.6007/IJARBSS/v9-i5/5840

DOI: $10.6007 /$ IJARBSS/v9-i5/5840

Received: 23 March 2019, Revised: 02 April 2019, Accepted: 30 April 2019

Published Online: 03 May 2019

In-Text Citation: (Wangui, Faith, \& Aketch, 2019)

To Cite this Article: Wangui, K. A., Faith, O. A., \& Aketch, N. 'ong 'a E. (2019). Strategies to Improve Performance Adopted By Social Enterprises in Kenya. International Journal of Academic Research Business and Social Sciences, 9(5), 52-77.

\section{Copyright: (C) 2019 The Author(s)}

Published by Human Resource Management Academic Research Society (www.hrmars.com)

This article is published under the Creative Commons Attribution (CC BY 4.0) license. Anyone may reproduce, distribute, translate and create derivative works of this article (for both commercial and non-commercial purposes), subject to full attribution to the original publication and authors. The full terms of this license may be seen

at: http://creativecommons.org/licences/by/4.0/legalcode

Vol. 9, No. 5, 2019, Pg. 52 - 77

http://hrmars.com/index.php/pages/detail/IJARBSS

JOURNAL HOMEPAGE

Full Terms \& Conditions of access and use can be found at http://hrmars.com/index.php/pages/detail/publication-ethics 


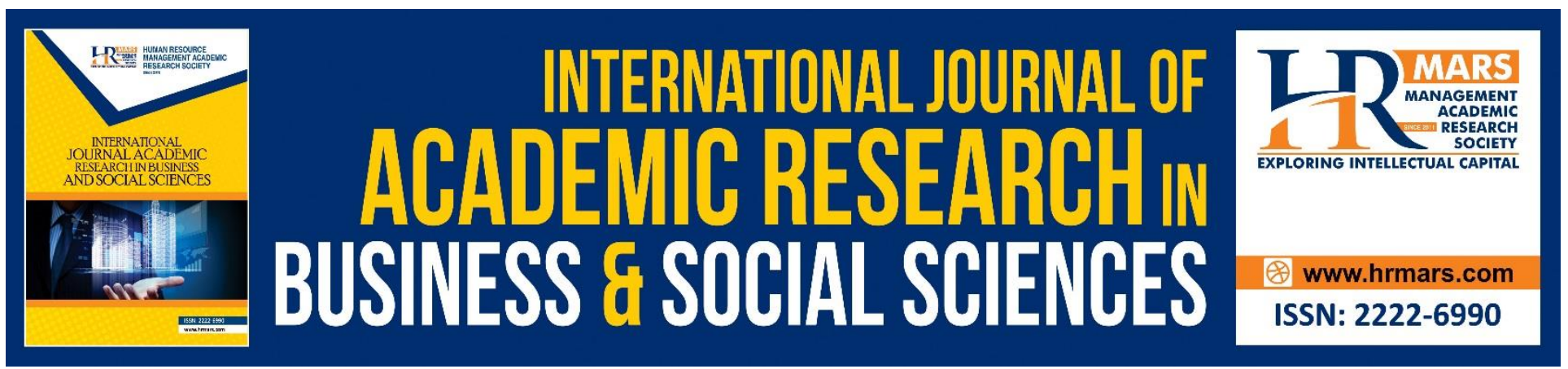

\title{
Strategies to Improve Performance Adopted By Social Enterprises in Kenya
}

\author{
Karanja Ann Wangu \\ Graduate, Master of Business Administration, University of Nairobi, Kenya \\ Email: wangui10@gmail.com \\ Odero Auma Faith \\ PhD Scholar, School of Business, University of Nairobi, Kenya \\ Email: faiodero07@gmail.com
}

Ng 'ong 'a E. Aketch, PhD

Email: aketchngonga@yahoo.com

\begin{abstract}
Organizations operate in open systems where a change in one sub system causes subsequent change in another subsystem. In a bid to remain relevant in their environment, social enterprises have to craft strategies. These strategies are used to ensure growth of the organizations. In some cases, the survival of some organizations is dependent on strategies. The study was carried out to determine strategies to improve performance adopted by social enterprises in Kenya. This study used the cross-sectional survey to understand strategies adopted by Social Enterprises in Kenya as well as to establish if such strategies influences performance of the Social enterprises in Kenya. The study used both primary data and secondary data. The primary data was collected by use of a semi structured questionnaire and administered to different strategic managers within the Social impact enterprises. The questionnaires were sent to 70 respondents, of which 31 responded, representing a response rate of $44 \%$. All the Social enterprises surveyed agreed that they have programs elaborating their strategic agendas. These formal programs formed the secondary data. Internal, external and environmental factors considered to be most influential on the strategic orientation of the social enterprises were; technology, management and resources. The study found out that PESTEL and SWOT analysis were the most common tools of analysis used in strategic planning amongst these social enterprises. However, they were limited by the fact that they did not offer a procedural way of strategy implementation. Findings revealed that the private sector was the greatest
\end{abstract}


competitor of social enterprises. The study findings established that the social enterprises used planned strategy, niche market competitive strategy and dominant market competitive strategies. The study concludes that the relationship between strategic planning and performance are inconclusive. The study recommends that every social enterprise has its own strength, and weakness and the best right means towards achieving sustained organizational performance would be amending strategy when changes occur in the external environment. The study further recommends that for government to strengthen the capacity of social enterprises it ought to partner with financial institutions by signing memorandum of understanding to inject capital. The study identified research areas for future studies; firstly, that in-depth analysis of single Social impact enterprises would give room to understanding key underlying variables that may have been globally over shadowed by findings in this study, social enterprises have not been studied in relation to change management.

Keywords: Strategies, Performance, Change Management and Social Enterprises in Kenya

\section{Background of the Study}

Organizations do not operate in a vacuum. They rather operate in a dynamic environment with active forces summarized by Michael porter in his five forces framework as; the bargaining power of supplier, threat of new entrants, threat of substitutes, bargaining power of buyers and industry rivalry. Since these organizations are a component of interconnected subsystems, a change in one subsystem impacts on the other subsystems that are in constant interaction with the environment. The environment in which organizations operate is highly unpredictable. These constant changes leave the organization with no choice but both proactive and reactive (plans and ploys) in responses to such environmental turbulence. Organizations are required to continuously adapt in a strategic fashion so as to remain relevant (Gathungu, 2008). While managers may be able to control and manipulate the immediate environment the remote environment does pose uncontrollable challenges that managers have to cope with for the success of their organization (Pearce and Robinson 2003). Change is inevitable. Its relevance to performance is however only achievable if the management of the organization steer it by evolving through the challenges, exploiting the emerging opportunities and ensuring its survival and success (Gathungu, 2008) through strategic alignment and realignment.

The term 'social enterprise' was coined in the UK, in reference to organizations that were using the power of business to bring about social and environmental change. The social enterprise community agrees that the primary aim of all social enterprises is anchored on positive social or environmental change (Social Enterprise UK, 2012). Despite Social enterprise being a new term in Africa, Kenya as a country has indicated its warmth to the concept. A fact that has well been brought out by the Kenyan Vision 2030 blueprint. The Blueprint has three pillars; economic, political and social pillar. All the pillars are interdependent with the latter aiming for just and cohesive society that enjoys equitable social development in a clean and secure environment (GoK, 2007). In the developing countries, social enterprise is a platform towards sustainability, growth and development as it cushions Government agency and Non -profit Making Organizations from the dependency syndrome, donor fatigue and a fatal collapse (Nganga, 2013). According to IMF (2006) 
INTERNATIONAL JOURNAL OF ACADEMIC RESEARCH IN BUSINESS AND SOCIAL SCIENCES Vol. 9, No. 5, May, 2019, E-ISSN: 2222-6990 @ 2019 HRMARS

developing countries Kenya included represent the most rapidly expanding economies and hence offer the most lucrative market for business. Yet despite all this they are a hot bed for social and environmental crises usually most acutely felt in the world (WRI, 2005; UNDP, 2006). Kenya being a technologically globalized with an advancing economy with regards to innovation, investment and business activity is likely to experience dramatic social and environmental impacts (positive and negative) (World Bank,2006). Of great relevance to this nation are the strategic measures put in place by social enterprises to incorporate social responsible investments aimed at impacting the society in the long term while remaining competitive.

Several studies on social entrepreneurships have been done in the western nations but still under researched in Kenya. Some studies in western nations includes; Principles for Social Investment (UN Global Compact, 2000), Social funds and decentralization: optimal institutional design (Faguet et al 2006), the landscape of social investment: Holistic topology of opportunities and challenges (Nicholls and Pharoah 2007), Impact Investments: An emerging asset class (Morgan Global Research, 2010), Microfinance and social investment (Conning \& Murdoch 2011), How to reinvent capitalism and unleash a wave of innovation and growth (Porter and Kramer, 2011), and Growing the SI market: 2013 progress update (UK.GOV, 2013). In Kenya, Allavida (2011) did a study on supporting the development of the Kenya Social Investment Exchange (KSIX), while Kinyua (2012) and Ndemo (2003) have researched on social entrepreneurship, Nganga (2013) researched on investment strategy adopted by NGOs/NPOs. With few or none documented studies on strategies adopted by social enterprises, the study was explorative.

\section{Problem Statement}

Recent times have witnessed an emerging debate on social enterprise that is slowly gaining momentum in the country. Social investment and enterprise is aimed at developing sustainable growth and development while creating a balance of service to community balance. This balance is strikingly difficult to maintain following the elusive nature of change in the business environment and the heightened global competition. Heller (1998) points out that understanding and managing change are dominant themes of management today. Adapting to ever changing present is essential for the success of the organization in the unpredictable future. Strategic responsiveness can be institutionalized within a firm through a series of related measures (Ansoff and Mc Donnell, 1990). A well-made strategy guides managerial action and thought. It provides an integrated approach for the organization and aids it in meeting the challenges posed by environment.

A number of studies on social enterprise have been conducted globally and/or abroad. UN Global Compact (2000) studied principals for social investment abroad. Faguet et al (2006) analyzed social funds and decentralization; optimal institutional design. Whereas the landscape of social investment: Holistic topology of opportunities and challenges was done by (Nicholls and Pharoah, 2007). Jackson et al (2012) undertook an independent evaluation of the work carried out in this arena where they found out that their existed a number of early successes and remaining 
INTERNATIONAL JOURNAL OF ACADEMIC RESEARCH IN BUSINESS AND SOCIAL SCIENCES Vol. 9, No. 5, May, 2019, E-ISSN: 2222-6990 @ 2019 HRMARS

challenges, many of which helped shape the activities that led to the origination and objectives of the currently ongoing research work.

In Africa, the Capital Markets Authority (2011), published a report titled: Impact Investing, Challenges and Opportunities in the East African Region. The report had a main focus on the ICT sector and sought to provide clarity on the kinds of opportunity available in the region. There have been numerous media articles on impact investing in the last two years. An indication that this study area is fertile for more research so as to uncover the unknown. In Kenya, Allavida (2011) tackled the development of Kenya Social Investment Exchange (KSIX). Ndemo (2003) worked on social entrepreneurship and so did Kinyua (2012). Nderitu (2004), Kiliko (2000) and Mitullah (1990) anchored their researches purely on Non -profit making organization and nongovernmental organization. Much more research has been conducted on strategy and organizational performance in profit making organizations. However, a significant gap was left by not addressing the strategies to improve performance adopted by social enterprises in service industry Kenya. This study is an effort towards addressing the existing gaps in knowledge. What strategies are adopted by social enterprises in service industry in Kenya?

\section{Purpose of the Study}

The aim of this study was to determine strategies adopted by Social Enterprises in Kenya and also to establish if such strategies influences performance of the Social enterprises in Kenya.

The study focused on three strategic management steps: concept of Strategy, Strategy Formulation and Social Enterprises in Kenya.

\section{Literature Review}

\section{Open Systems Theory}

Organizations are composed of a number of interconnected subsystems. A change in one subsystem impacts on the other subsystems. The environment interferes with organizations because they are open systems (Burnes, 2004). Such forces within the environment are regarded as drivers of change. The forces are of two types; internal and external. Whereas the internal forces include change in size of the organization, performance gaps, employee needs, values and change in the top management the external forces include technology, business scenario and environment factors (Sengupta and Hattacharya, 2006). When organizations are operating on a volatile environment they may not always direct change in a planned fashion. Thus changes may occur spontaneously or randomly in an organization (Otieno, 2011).

Organizational development is a fabric of relationships, values and norms that bind people together and gives them a sense of belonging to the particular society. For an organization to achieve transition from a current state to a desired future state, individuals and teams must be involved. Individual behavior is learned through some external stimulus like rewards, punishment and reinforcement. Individual behavior affects the group environment because individuals behave in a way to conform to group pressures, norms, role and values. This in turn affects the organizational culture (a system of shared assumptions, values, and beliefs, which 
INTERNATIONAL JOURNAL OF ACADEMIC RESEARCH IN BUSINESS AND SOCIAL SCIENCES Vol. 9, No. 5, May, 2019, E-ISSN: 2222-6990 @ 2019 HRMARS

governs how people behave in organizations.) and may unwoven the structure which conjoined by a unity of purpose.

\section{Resource Based View}

The resource-based theory grew from the work of economists who in searching to identify the factors which gave rise to imperfect competition and supernormal profits drew attention to differences between firms in terms of technical know-how, patents, trademarks, brand awareness and managerial ability (Burnes, 2004). The resource-based view as a basis for the competitive advantage of a firm lies primarily in the application of a bundle of valuable tangible or intangible resources at the firms' disposal (Mwailu and Mercer, 1983; Wernefelt, 1984; Rumelt, 1984; and Penrose, 1959). Prahalad and Hamel (1990) argue that the real competitive advantage comes from the ability to build at lower cost and more speedily than competitors.

This framework postulates that resources are what help a firm exploit opportunities and neutralize threats and so achieving competitive advantage requires that a firm effectively deploy superior or unique resources which allow it to have lower costs or better products rather than technical maneuvering or product market position (David, 2007). In order to transform a short run competitive advantage into a sustained competitive advantage, it requires that the firm resources are heterogeneous in nature and not perfectly mobile (Peteraf, 1993). Effectively, this translates into valuables resources that are neither perfectly imitable nor substitutable without great effort (Barney 1991) If these conditions hold the bundle of resources can sustain the firms above average returns.

The assumption of the resource based view is that the mix, type, amount and nature of a firms internal resources should be considered first and foremost in devising strategies that can lead to sustainable competitive advantage(Hoskinson,1987).Thus managing strategically involves developing and exploiting a firms unique resources and capabilities continually maintaining and strengthening such resources(Burnes,2004).This theory is therefore a method in strategic management of analyzing and identifying a firms strategic advantage based on examining its distinct combination of assets, skills, capabilities and intangibles of the organization. The social enterprises seek continuity and sustainability. The RBV provide an angle through which such sustainability and improved performance can be achieved.

\section{Environmental Dependence Theory}

Organizational behavior is affected by external resources. The procurement of external resources is an important tenet of the strategic management of an organization. This theory has implications regarding the optimal divisional structure of organizations, recruitment of board members and employees, production strategies, contract structures, external organizational links and many other aspects of organizational strategy (Preffer and Salancik, 1978). The basic arguments of environmental dependence theory are that; organizations depend on resources which ultimately originate from its external environment. The environment to a considerable extent contains other organizations. The resources needed by one organization are often in the 
hands of another organization hence these resources are a source of power. Hence power and resource dependence are directly linked (Heyward and Boeker, 1998). Power is thus relational, situational and potentially mutual (Heyward and Boeker, 1998).

According to Drees and Heugens (2013) organizations depend on multidimensional resources such as; labor, capital, raw materials et cetera. Organizations may not be able to come out with countervailing initiatives for all these multiple resources. Hence organizations should move through the principle of criticality and the principle of scarcity. Critical resources are those the organization must have to function (Davis and Cobb, 2010).

Whereas all organizations are environmental dependent and environment serving, social enterprises have become more strategic with regard to their performance in recent times (Boyd, 1990). Scholars have argued that this theory is one of the main reasons why less government grants are being committed in social service (Eikenberry, 2004). Hence opening up social services for commercialization. A factor that was unheard of in the recent past. On the other hand, contract competition between private and non- profit organizations has increased. There by providing a breeding ground for a more accommodative and sustainable means of meeting social needs while making profits through social enterprise.

\section{Types of Strategies}

Enterprises can adopt various strategies for survival and improved performance. Several strategies are discussed below.

\section{Planned Strategy}

The planned strategy is clear intentions backed by formal control. The leader is the center of authority with their intentions being very clear and precise and the goal is to transform the intention to collective action with minimum distortion. Programs and systems are built in to the plan to ensure that no one act in another way than intended. For this type of strategic process to be effective, the environment has to be extremely stable or the organization has to be able to predict it with great accuracy. When organizations put large quantities of resources in a mission or project, they might not tolerate unstable environment.

\section{Umbrella Strategy}

Mintzberg and Waters (2001) relax the condition of tight control over the actors in the organizations and in some case, control over the environment. Leaders have only partial guidelines for behavior, defined boundaries and the other actors in the organization can maneuver within these parameters. This means that strategies can emerge within these boundaries. The umbrella strategy cannot only be labelled as deliberate and emergent but also deliberate emergent in the sense that the central leadership creates conditions which allow strategies to emerge. Like the entrepreneurial strategy, there is a certain vision emanating from the central leadership. 


\section{Institutional Competition- Governance (IC-G)}

Firms competing for the advantages of higher standards of corporate governance including the indirect benefit of increased institutional support are distinguished by ongoing internal process aimed at raising governance of the firm. Such firms are said to be following an IC-G strategy. ICG strategy can be defined as a strategy whereby the firm aims specifically to increase its comparative power and reduce that of its competitors by increasing its standards of corporate governance, distinctly and individually. These competitor firms will enjoy the benefits of high governance standards, such as legitimacy and a positive social image amongst consumer.

\section{Opportunistic Strategy}

According to Palatino and Seifert (1997) the firm using an opportunistic strategy deviates from plans easily when opportunities occur. Plans are constantly being adjusted. Thus, this strategy is not top down and systematic. On the other hand, opportunistic strategy is not completely driven by the situation as is the reactive strategy. It is much more proactive.

\section{Unconnected Strategy}

The unconnected strategy is perhaps the most straightforward of all. One part of the organization, a subunit or sometimes even an individual can realize its own pattern in its stream of action. Since these unconnected strategies do not come from the central leadership or from intentions the whole organization, they can be considered relatively emergent. But the subunit/Individual, they clearly can deliberate or emergent depending on the prior existence of intentions. Thus, the unconnected strategy may be deliberate or emergent. But for the subunit/individual, they clearly can be deliberate or emergent depending on the prior existence of intentions.

\section{Consensus Strategy}

In this strategy, the conditions for prior are totally dropped. This type of strategy is clearly emergent. In this strategy different actors converge on the same pattern or theme so that it becomes pervasive in the organization, without need for central direction or control. The consensus strategy grows out of the mutual adjustment among the different actions as they learn from each other and from their responses to the environment and thereby finds a common pattern that works for organizations. This means that the convergence is not driven by intentions by management or by prior intentions shared by the organizations as a whole; rather it evolves around the result of a host of individuals' actions. Sometimes actors might promote the consensus and try to negotiate others to accept it, but the point is that this strategy comes more from collective actions than from collection intentions.

\section{Dominant Market Competition Strategy}

According to Wee (2001), firms within the same quadrant are not likely to have a difference in comparative power that is large enough to give one firm a significant competitive edge over another. This is because definition, comparative power of a firm increases, it also pushes up the environmental average, causing a marginal decrease in the comparative power of firms in more 
INTERNATIONAL JOURNAL OF ACADEMIC RESEARCH IN BUSINESS AND SOCIAL SCIENCES Vol. 9, No. 5, May, 2019, E-ISSN: 2222-6990 @ 2019 HRMARS

preferred quadrants. For this reason, firms which perceive themselves as being higher or equal in comparative power, are likely to pursue traditional competition strategies and not aim to compete on the basis of increasing their comparative power (Peng and Luo,2000). These firms towards taking in a competitive lead in the market, usually through aggressive business tactics.

\section{Niche Market Competition Strategy}

This is competing on the basis of market performance in tune with prevailing strategies of market competition, when the firm perceives its comparative power to be lower than that of its competitor is such that the attempts to increase the firm's level of support or standards of its competitor. Firms may believe that the discrepancy in comparative power between itself and its competitor is such that attempt to increase the firm's level of support or standards of governance may not be efficient in bridging the gap, especially given the resources required for the task. Such firms may also compete based on more traditional strategies, in order to ensure their own survival. Such a firm attempt to create a niche for itself, rather than compete directly (Whitley, 2002).

\section{Challenges Faced by Social Enterprises}

Social enterprises face various challenges. Lack of adequate financial resources is one such challenge. Financing is what enables them to hire talent, market services and products, rent space and carry out other activities related to growing their organizations. Funding depends largely on their maturity, reputation and legal structure (Smith and Darke, 2014). In the attempt of social enterprises to access external finance, they face many challenges compared to their mainstream business counterparts (World Bank, 2006).

The Government has not provided enabling legal structures for startups. For instance, funding can be a good source, but it tends to favor established organizations. Firstly, registering an enterprise is expensive in Kenya (Jackson and Associates, 2012). Secondly, High taxes (Depending on whether you qualify as a "resident" or "non-resident" company, income tax on net trading profits can be as high as $40 \%$.) Thirdly, stringent requirement is a prerequisite for financing.

In adequate human resource has manifest its self on a number of ways such as a lack of local highly qualified personnel who are able to execute their mandate at work properly thus leading to slowing down of business processes and incursion of extra costs for sub-contractors and expatriates (Heller,1998). Defourny and Nyssens (2010) elaborate that another form of this inconsistency is where employees do not take their employment contract seriously and often chose to abandon their work when they should give a minimum notice of four weeks to their employers. The turnover of employees is high in social enterprises because returns on investment, time, effort and energy spent are not so quick to give a proportionally equivalent return as in regular business (Jackson and Associates, 2012). This is due to the challenges of engaging in social enterprises and expecting compensation for it whereas in the past only Non-Governmental organizations or Government were interested in identifying solutions to social issues. 
The general challenge of the funders is the sense that the entrepreneurs identified as beneficiaries lack the proper management skill set to efficiently run a business and make it sustainably profitable. Some of the management skills involved here include; sound financial management, human resource management and leadership, change and risk management and the technological competence required. This then means that the business will not only require the funding and the business support but also training for the management team as well if the enterprise is to grow at all (CMA,2011). A reason for this lack of skills among the Kenyan entrepreneurs is the lack of affordable training on such skills, which means that talented and smart business men who want to engage in social ventures risk being locked out of such good learning opportunities due to high costs associated with it (World Bank, 2006).

There is a lack of innovative and creative business ideas to solve some of the social problems in the society. Previously, funders have had a challenge of finding worthy investments, either due to business ideas lacking a social impact aspect or due to the social impact being carried out in ways that have already been explored and maybe even exhausted (Nderitu, 2004). Therefore, a lot of businesses end up not being funded due to the fact that they are not creative enough or that they lack a substantial social impact component. There is also the problem of balancing the innovations in the investments with the sustainability of the business which most entrepreneurs struggle with (Allavida, 2011). The other challenges that was identified involved, lack of transparency of the enterprises, lack of good market information, unregulated competition, long process of institutionalizing SMEs, currency and inflation issues resulting from funding in other currencies other than Kenya Shillings. The other challenges that were sector specific as outlined by Capital markets (2011) are the inadequate security and safety of the agricultural products (being open to weather conditions and destruction by man and animal) and the disorganized agricultural sector in Kenya in comparison to other East African countries and lastly, heavy political interference in the agricultural sector that greatly hampers its development.

Previous studies, such as Nganga (2013) found that impact measurement was one of the most difficult things to accomplish, according to the entrepreneurs that were interviewed. This was due to the fact that there are no standard metrics to be used to measure social and environmental impact (WRI, 2005). The existing metrics used are far from accurate and they can only measure quantitative facts and neglect the qualitative aspects present in reality. Each of the funds had the following response in regard to the measurement of impact.

\section{Study Methodology}

This research was exploratory in nature so that all the possible research angles are opened up for critique and analysis of problem. Investigators use these methods, which they refer to collectively as exploratory research, with a single purpose: clarify the research questions which guide the whole research project. Mugenda and Mugenda (2003) exploratory research is beneficial because: One, it increases understanding (The main objective of exploratory research is to improve a researcher's knowledge of a topic. It helps an investigator begin to determine why and how things happen). Two, concept testing (A typical basis for performing exploratory work is to check concepts if they are not well established, usually a very costly endeavor). Three, 
assistance to researchers (It assists researchers to find potential causes to the signs or symptoms conveyed by decision makers).

Data was collected through questionnaires containing both open ended and closed. The guide was divided into three sections. Section I captured information on the general background of organization. It is intended that Section II respond to the first objective of the study which is to determine strategies adopted by Social Enterprises in Kenya. Section III sought to establish the relevance of such strategies on the performance of the enterprises in service industry in Kenya. The secondary data was used to capture historical data that respondents seldom remember. The sources of such data would be any official documents that would be deemed relevant to supply this study with substantive information. The primary and secondary data would complement each other so as to cover on areas that each may be disadvantage. The nature of data collected was both quantitative and qualitative. The quantitative aspect majorly focused on variables of measurement. Abbott (1994) indicates this by his statement that quantitative method involves simple quantification of activities such as employee turnover, customer retention, cost reductions and turn-around-time. The qualitative perspective of this study would address the why and how. It was intended to capture the descriptive findings of this study. Lincoln and Guba (2000) elaborated that qualitative research involves an interpretive and naturalistic meaning.

Analysis was conducted through conceptual content analysis which is a flexible methodology in measuring the semantic content while overriding the thematic issues in qualitative data. According to Berelson (1952) conceptual content analysis is a research technique for the objective, systematic and quantitative description of the manifest content in an organization. It is further advantaged in this project because it allows for both quantitative and qualitative operations while providing insight into complex models of human thought and behavior as is the case with executives with regards to strategic management in an organization. Conceptual content analysis has the ability to examine patterns of symbolic meaning by both observation and in text, and by allowing data to be transformed into numbers and be presented in form of tables, histograms, graph and pie charts. Kinuu, Maalu and Aosa (2012) used this valuable technique of analysis in their study. The intent of conceptual content analysis is to discern whether there is some pattern in the values collected and the intention is to use the patterns for forecasting and as a basis of business decisions making.

\section{Study Findings}

\section{Life Span of Social Enterprises in Kenya}

Out of the thirty-one social enterprises surveyed five that is fourteen percent indicated to have been in existence between one to five years. Fifteen of them indicated that they had been in operations for a period more than six years and less than ten years that is forty- three percent. Twenty-nine percent had been in existence between eleven to fifteen years whereas fourteen percent of the social enterprises had been in existence for more than sixteen years, hence, representing ten and five social enterprises respectively. 


\section{Social Enterprises Operation Period}

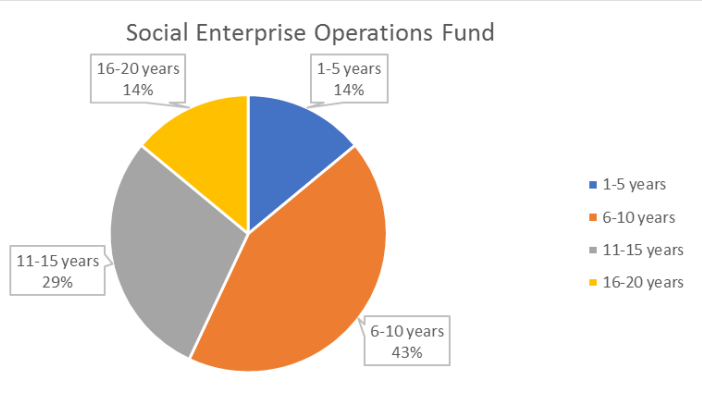

Figure 1: Duration of Existence of Social Enterprise

The Size of Social Enterprises in Kenya

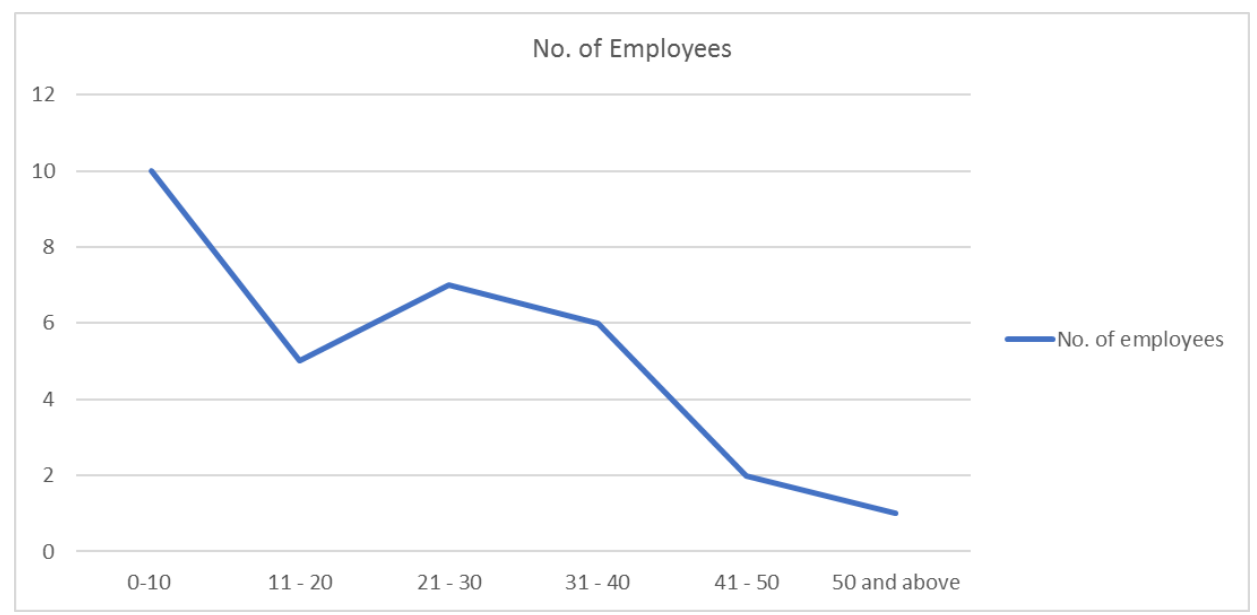

Figure 2: A graphic representation of the number of employees in the Social Enterprises in Kenya

Ten out of the thirty-one social enterprises depicted that they had between one and ten employees. Five of the social enterprises indicated to have between eleven and twenty employees. Seven of the social enterprises had seven employees. Six social enterprises had between thirty-one and forty employees. Two of the enterprises had a population of between forty-one and fifty employees. Only one social enterprise had more than fifty- one employees. 


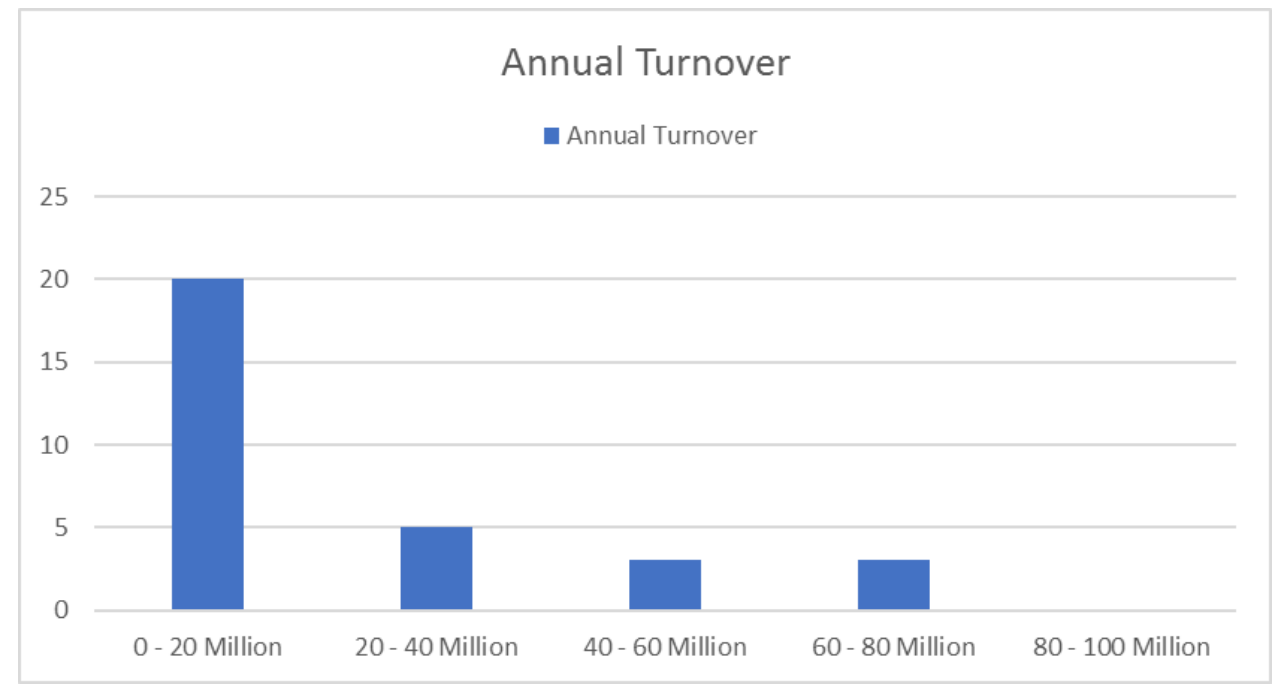

Figure 3: Graphical representation of Social Enterprise Annual Turn Over

Twenty social enterprises out of thirty-one indicated a turnover of between zero to twenty million. Five social enterprises indicated a turnover of between twenty-one million to forty million. A turnover of forty-one to sixty million was indicated by three social enterprises so was a turnover of sixty-one to eighty million. None of the social enterprises indicated a turn over above eighty-one million.

\section{Social Enterprises Orientation}

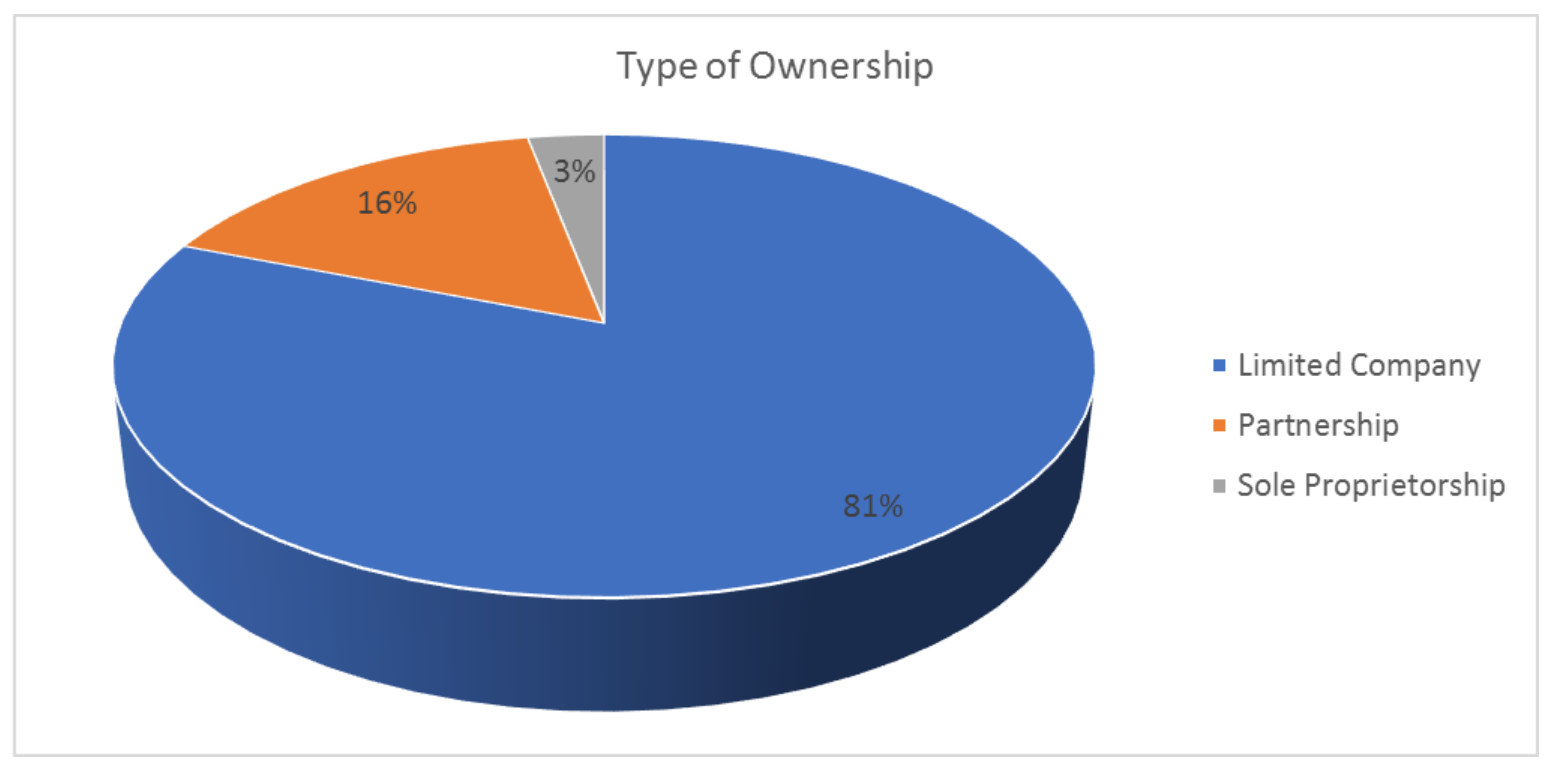

Figure 4: Pie Chart Representation of Social Enterprise Nature of Ownership

Eighty-one per cent that is twenty-five out of thirty-one of the social enterprises were found out to, be limited companies where as three per cent that is one social enterprise was found to 
be a sole proprietorship. Sixteen per cent of the social enterprises were found out to be partnerships; this makes up five of the thirty-one social enterprises.

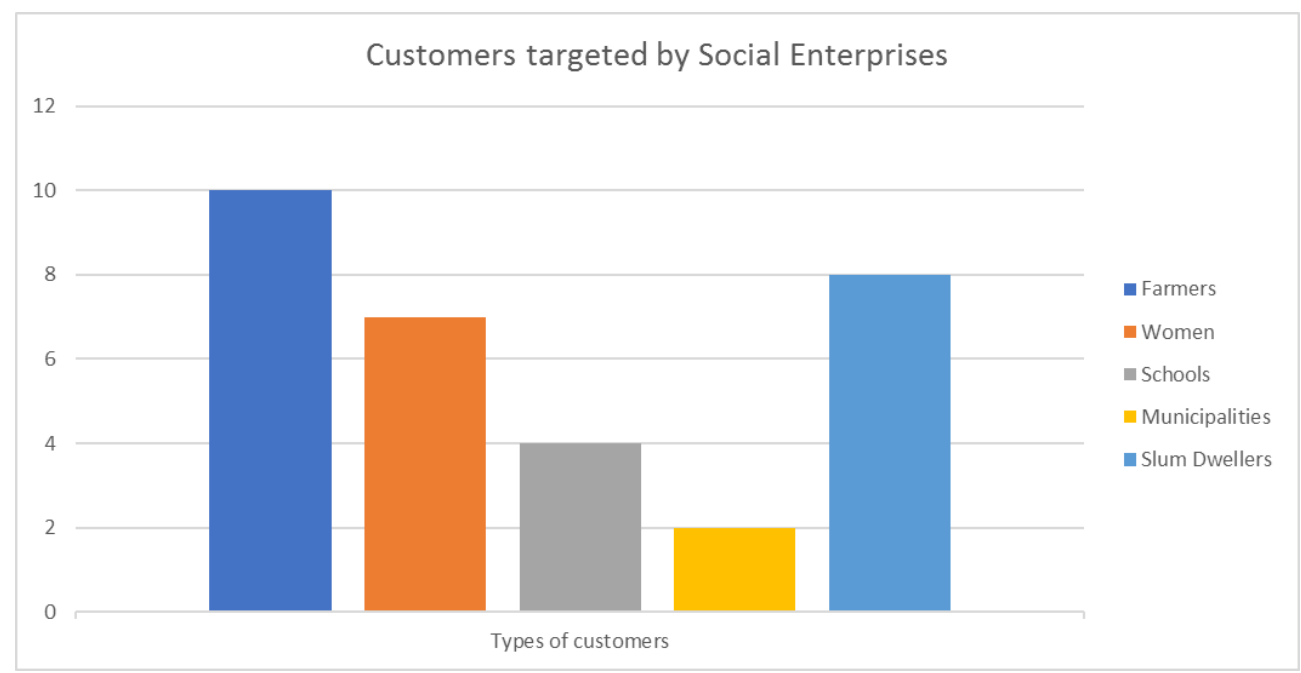

Figure 5: Graphical representations of Customers targeted by Social Enterprises

Findings reveled that ten of the thirty-one social enterprises targeted farmers as their primary customers. Seven of the social enterprises had women as their target customers. Slum dwellers or rather those who live below a dollar a day (the poor), were the target customers for eight social enterprises. Schools and municipalities were least targeted by four and two social enterprises respectively. 


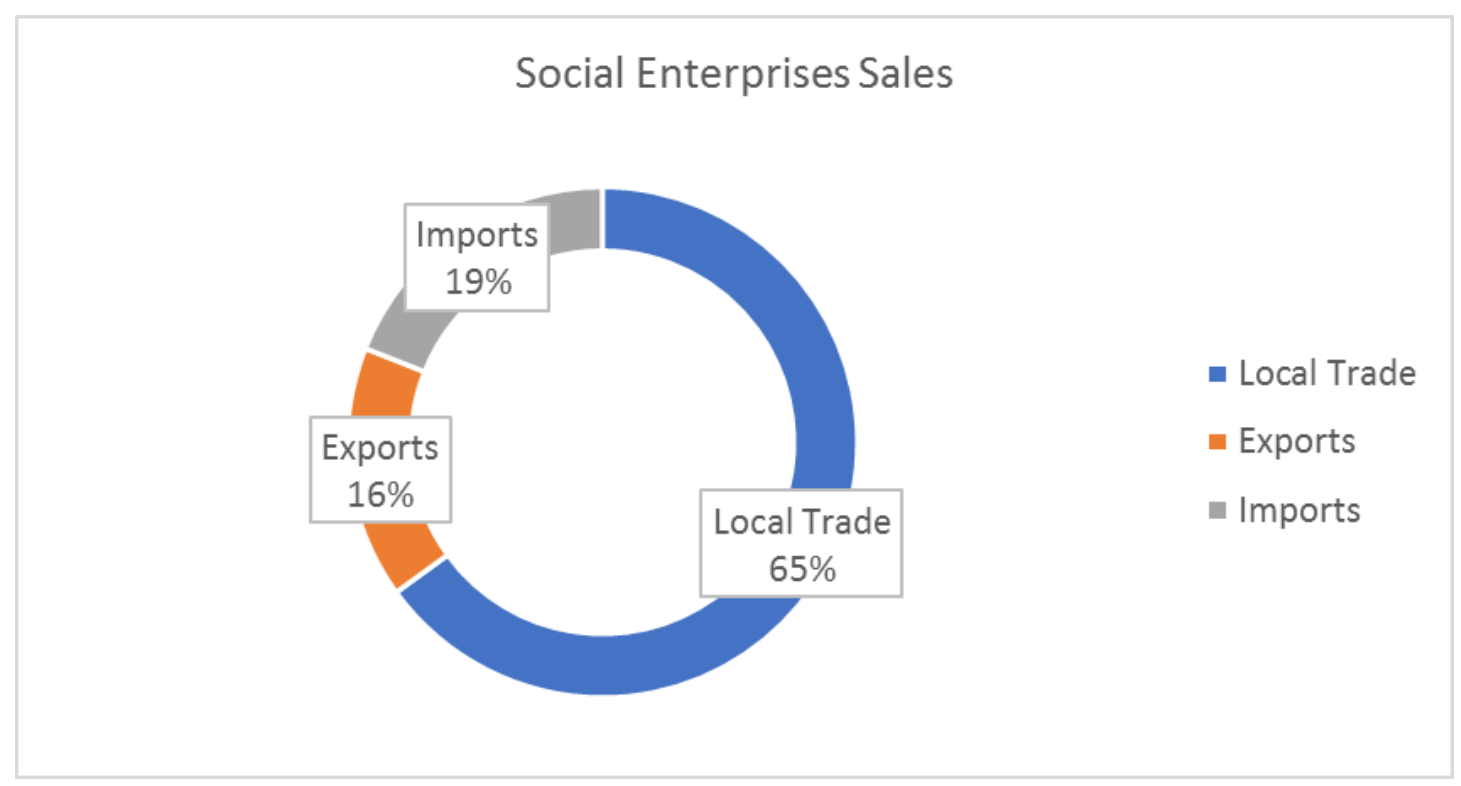

Figure 6: Doughnut Chart representations of type of trade embraced by Social Enterprises

Sixty-five per cent of the social enterprises indicated that their sales majorly came from local transactions' that is twenty of the thirty-one social enterprises surveyed. Thirty-five per cent of the social enterprises involved themselves with international trade of which sixteen per cent got their sales from exports and nineteen per cent of the social enterprises got their sales from imports.

\section{Competitors of Social Enterprises in Kenya}

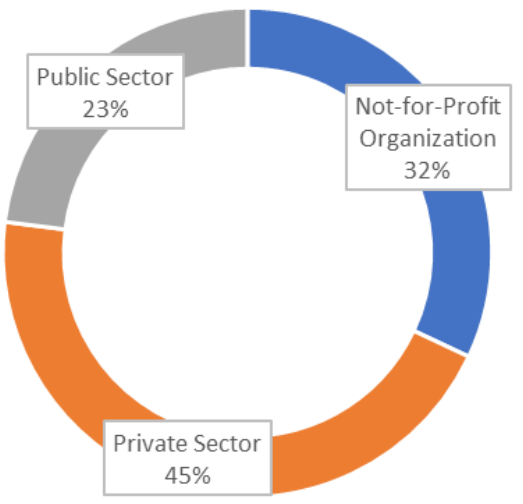

- Not-for-Profit Organization

- Private Sector

- Public Sector

Findings revealed that that the private sector was the greatest competitor of social enterprises standing at forty-five per cent followed by the Not for profit organizations at thirty-two per cent and finally the public sector at twenty-three per cent. 
INTERNATIONAL JOURNAL OF ACADEMIC RESEARCH IN BUSINESS AND SOCIAL SCIENCES

Vol. 9, No. 5, May, 2019, E-ISSN: 2222-6990 @ 2019 HRMARS

\section{Strategies Adopted by Social Enterprises}

This second section of the data findings sought to find out whether the social enterprises have strategic plans, how they establish their strategic goals, what factors influences their choice of strategies, what are the objectives of their chosen strategies and what challenges they (social enterprises) face during the implementation phase.

\section{Formation of Social Enterprises Strategic Goals}

All the thirty-one social enterprises surveyed agreed that they have programs elaborating their strategic agendas. These programs were sited to be in form of financial plans, human resources plans, sales and marketing plans. It was found out that the plans were meant to be implemented between durations of three to five years.

Table 1 below highlights that fifty-one percent of the social enterprises used both the PESTEL and SWOT analysis in strategic planning. On the other hand, twenty-three per cent of the social enterprises used the SWOT analysis only to formulate their strategic plans. However, the remaining twenty-six per cent used the PESTEL analysis to craft their strategies.

Table 1: Social Enterprise Analysis Tools

\begin{tabular}{|l|c|c|}
\hline Variable & Frequency & Percentage \\
\hline $\begin{array}{l}\text { Formation of strategic goals by assessing the environmental } \\
\text { problems and opportunities. }\end{array}$ & 7 & $23 \%$ \\
\hline $\begin{array}{l}\text { Formation of strategic goals by assessing the firm's strengths and } \\
\text { weaknesses. }\end{array}$ & 8 & $26 \%$ \\
\hline Formation of strategic goals by both above & 16 & $51 \%$ \\
\hline Total & 31 & $100 \%$ \\
\hline
\end{tabular}

\section{Factors Influencing Social Enterprises Strategic Orientation}

As indicated by figure 8 below, twenty percent of the social enterprises indicated that their strategic orientations were majorly influenced by the internal factor. Forty percent of the social enterprises felt that their strategic orientation is influenced by external environmental factors. The remaining forty percent felt that their strategic orientation was somewhat influenced by both internal organizational factors and external environmental factors. 


\section{Factors Influencing Social Enterprise Strategic Orientation}

- Internal Factors - External Factors = Both

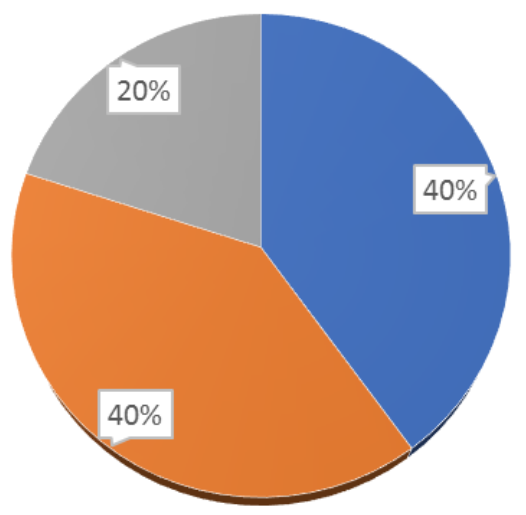

Figure 8: Pie chart Representation factors influencing Social Enterprise Strategic Orientation

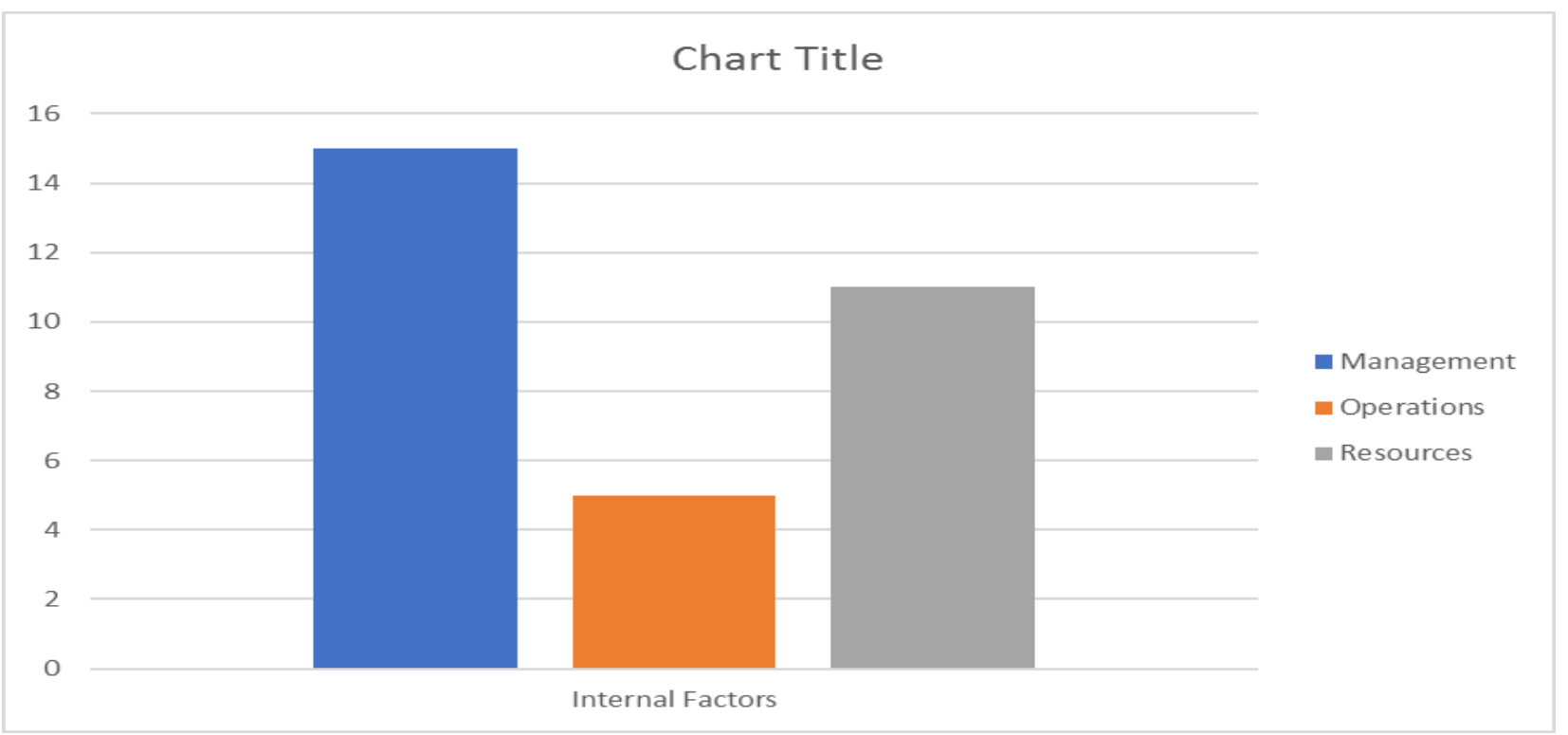

Figure 9: Internal Factors Influencing Social Enterprise Strategic Orientation

When the respondents were asked which internal factors they felt influenced their strategic orientation, the answer that they gave fell into the three categories; management, operations and resources. Fifteen of the respondents felt that it was management and management related 
issues that affected their strategic orientation. Eleven of the social enterprises felt that it was the organizational resources that affected their strategic orientation. Whereas five felt that actually their strategic orientation was affected by the organizational operations.

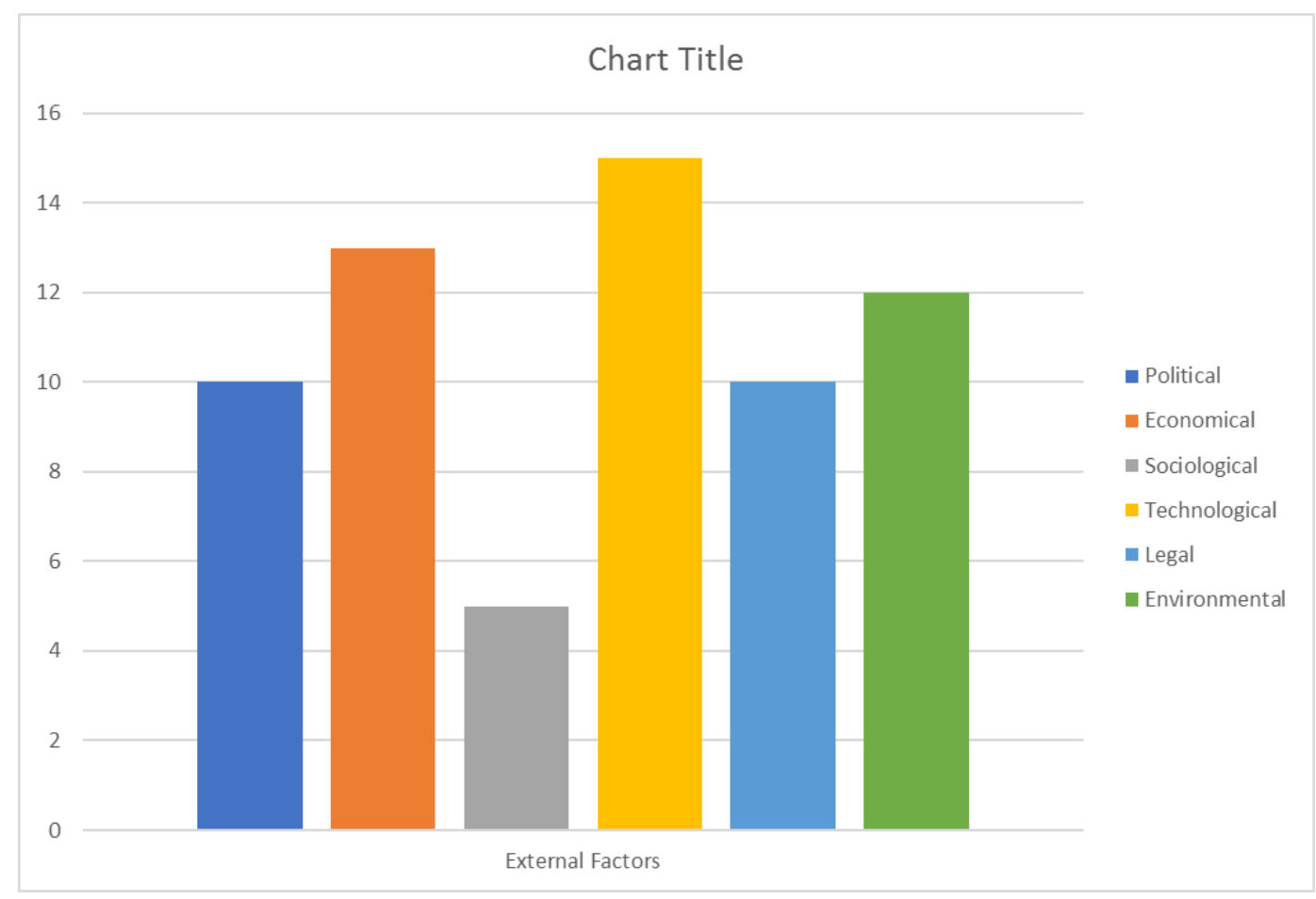

Figure10: External Factors Influencing Social Enterprise Strategic Orientation

Majority of the respondents that is seventeen of the social enterprises when asked which external environmental factor affected them the most listed technological factors. This was followed by environmental factors (which were indicated by twelve respondents) and economic factors (which were indicated by thirteen respondents). Legal and political factors were cited by ten social enterprises each. Sociological factors were the least cited by five social enterprises to be of influence to their strategic orientation. When the respondents were asked whether their social enterprises conduct interdepartmental meetings to discuss strategic moves and developments in the industry, seventy-five per cent said yes whereas twenty-five percent said no. Those that said yes elaborated that all departments within the social enterprise were involved in strategy formulation. However, one social enterprise stated that they had a department that was wholly dedicated in strategy planning, implementation and evaluation. This social enterprise highlighted further that the particular department worked closely with other departments on the role that the various departments are to play during strategy implementation.

When responding on what they (respondents) felt were their social enterprises weaknesses in terms of strategy formulation, seventy percent of the respondents stated lack of technocrats in 
the field of strategic management. The remaining thirty per cent highlighted lack of specificity and clarity on the steps to be taken by the strategic managers after conducting SWOT and PESTEL analysis. The respondents were asked, what challenge their social enterprises faced in implementing the adopted strategies. They listed lack of good will by other stakeholders, limited resources, measurement issues, constant environmental dynamics and lack of technocrats who can keep monitoring and evaluating the strategy implemented.

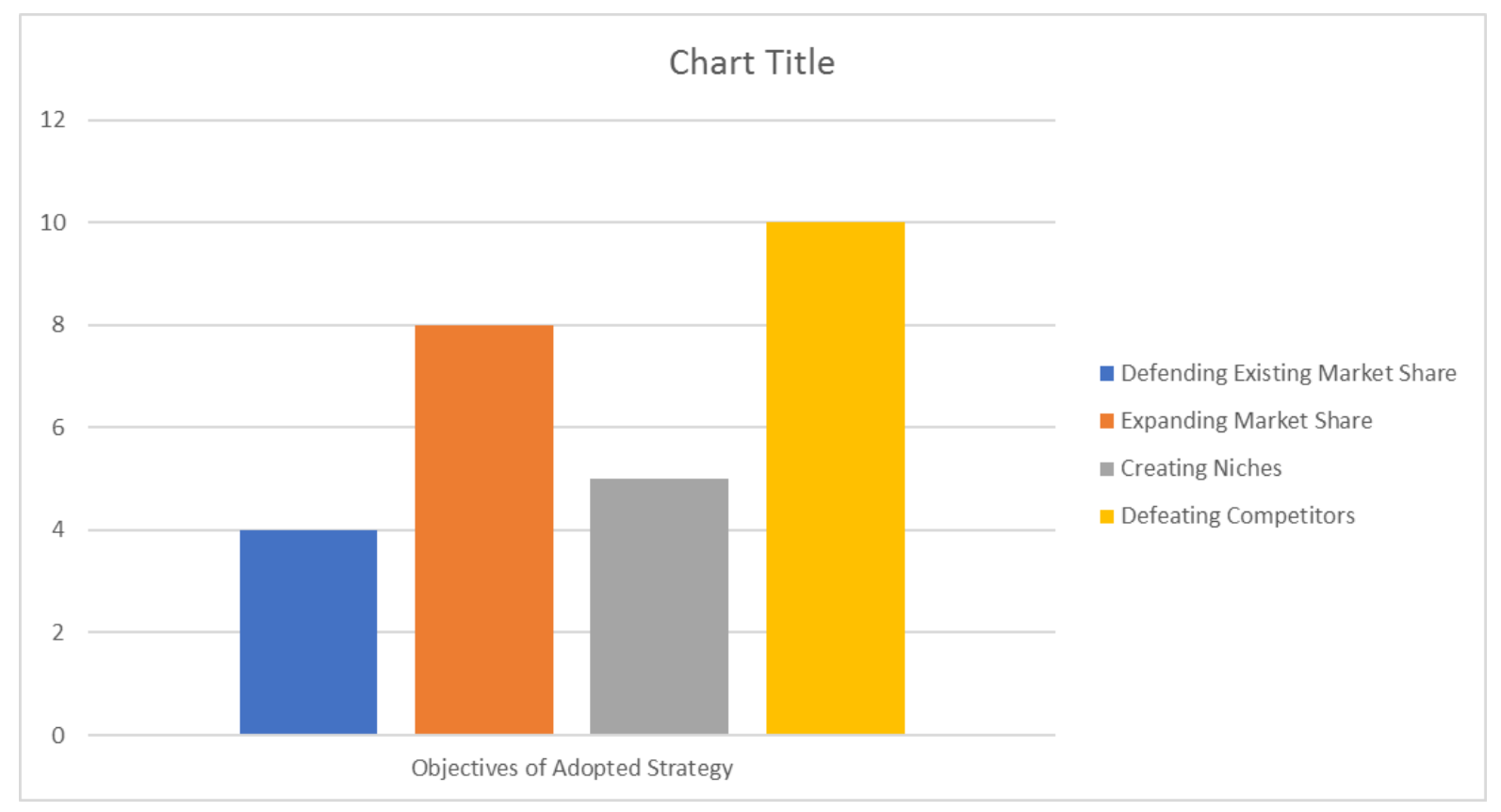

Figure11: Objectives of the Strategies adopted by Social Enterprises

Ten out of the thirty-one social enterprises informed the researcher that their strategy was meant to defeat their competitors. Eight of the social enterprises had strategies that were meant to expand their market share. Five of the social enterprises listed their strategic objective as creation of new niches. Four social enterprises created a strategy with the intention of defending their existing market share. 
INTERNATIONAL JOURNAL OF ACADEMIC RESEARCH IN BUSINESS AND SOCIAL SCIENCES Vol. 9, No. 5, May, 2019, E-ISSN: 2222-6990 @ 2019 HRMARS

\section{Effects of Strategies Adopted on Performance of the Organization}

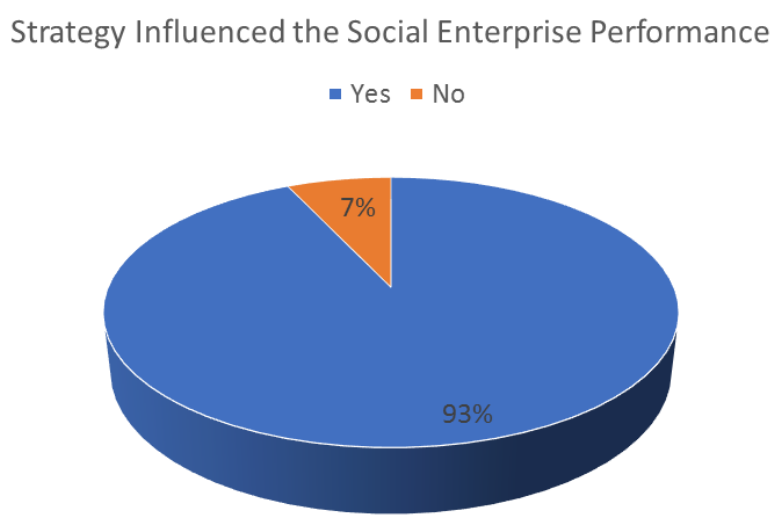

Figure12: Pie chart presentation of Influence of Strategy on Social Enterprise Performance

Ninety-three percent of the social enterprises indicated that the strategy that they adopted influenced the performance of the organization. That is twenty-nine of the thirty-one social enterprises. The remaining two make the seven percent of the social enterprises which felt that the strategy that they adopted did not influence performance.

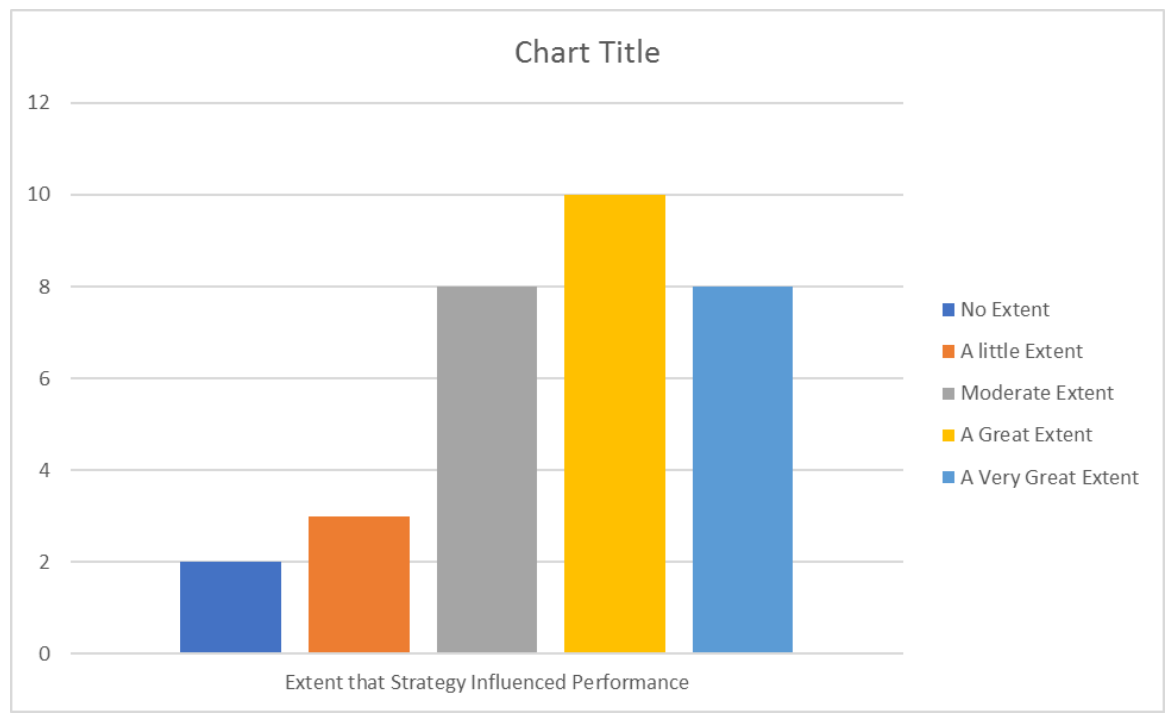

Figure13: Bar graph presentation of the extent that Strategy influenced performance 
INTERNATIONAL JOURNAL OF ACADEMIC RESEARCH IN BUSINESS AND SOCIAL SCIENCES Vol. 9, No. 5, May, 2019, E-ISSN: 2222-6990 @ 2019 HRMARS

Two of the social enterprises felt that strategy did not influence the performance of their organization to any extent. Three of the social enterprises felt that strategy influenced performance to a little extent. Eight of the social enterprises felt that strategy influenced their performance moderately and to a very great extent. Ten of the social enterprises felt that strategy influenced their performance to a great extent.

\section{Discussion of Findings}

This section discusses the findings of the study. It relates these findings to the objectives of the study as well as the existing literature. The findings of this study revealed that Social Enterprises' in Kenya use different strategies to improve their performance. This goes hand in hand with the first research objective; which is to determine strategies adopted by Social Enterprises in Kenya. Social enterprises find it difficult to compete with other sector players such as the public and private sector while remaining profitable. This follows the difficulty in balancing the act of social impact and sustainability. Forty- five per cent of the respondents indicated that they believed their competitors were in the private sector. The private sector players challenge the social enterprises greatly because of their financial muscles whereas the public sector players challenge the social enterprises in pricing. Fifty-seven per cent of the social enterprises stated that they have been in existence for less than ten years; an indication that most social enterprises are basically startups in Kenya and that their limited resources are extremely stretched for them to compete and beat the public and the private sector players. Eighty-one per cent revealed to be limited companies with about twenty having a turnover of between zero to twenty million.

Social Enterprises in Kenya use a range of strategies that ensure their success and at times their survival in cases of volatile markets. Twenty-six per cent of the respondents' agreed that their strategy was meant to capture a larger market share. According to Ansoff (1987) for entrepreneurial organizations to have larger market territories' they ought to get new products into new markets. The findings also revealed that thirty-two per cent of the Social Enterprises were using strategies that ensured they out did their rivals. Fifteen out of the thirty-one respondents indicated that they have lean but effective human resource that is less than twenty employees. This according to the respondents is a cost cutting measure that is meant to reduce their operating cost. Hence reduce the product or service cost that the customer is being offered beyond that which is being offered by the competitor. This way the social enterprises increase their revenues beyond that of competitor and they earn a larger market shares than their rivals. According to Pearce and Robinson (2011) for organizations to achieve competitive advantage they need to adopt low cost leadership.

Pearce and Robinson (2011) further state that low cost has an advantage as it reduces the attractiveness of substitute products in the industry. Sixteen per cent of the social enterprises indicated that their performance improvement strategy was inclined towards development of new market niches. This was supported by the way they described the products and services that they offered to their customer. For instance, Takamoto Biogas builds biogas systems and supplies 
biogas appliances to rural farmers in Kenya with the objective of creating energy security, improving the quality of life and protecting the earth's natural resources. Ecotact on the other hand provides sanitation facilities to the urban people in slums, town centers and schools. Their business model involves optimizing social responsiveness as well as ecological systems such as low water sanitation systems, which reduces water consumption and increase human waste recovery in terms of energy (methane) and nutrients (nitrates and Phosphates). According to Barney (2007) through product differentiation customers become more willing to pay for the products and services. This helps the firms to have products and services that are unique from what the competitors have. This strategy allows the social enterprises to offer products and services that the customers perceive to be of higher quality than the competition (Pearce and Robinson, 2011).

Five out of thirty-one Social Enterprises elaborated that their strategic orientation involved defending their market share. These social enterprises depicted that they knew who their customer were; be they farmers, women, schools' municipalities or slum dwellers. Therefore, the Social enterprises used value addition strategies to meet their clients' needs and customer care endeavors to sustain their customer business relationships. According to Porter (1985) social enterprises need to adopt the value chain analysis in order to create competitive advantage. This means that the Social enterprises understand their customer needs and offer products and services that the customers feel they are getting value for. Customer business relationship is also very important if the organizations need to maintain its market share. It entails knowing what the customer needs are and how best to satisfy those needs (Kotler, 2000). These strong marketing activities ensure that organizations achieve sustained competitive advantage. The marketing activities involve advertising, on time deliveries and promotions. This ensures loyalty and retention of customers. The study also revealed that the smaller social enterprises that are solely owned which make up three per cent of the respondents, used collaborative means to ensure that they defend their market share. These collaborative strategies include forming strategic alliances. This is supported by Barney (2007). Kenya being a developing country has very few companies with the capabilities required to enter into a new market and thrive there in. It is therefore important.

The second research objective was to establish if such strategies influences performance of the Social enterprises in Kenya. Ninety-three per cent of the social enterprises stated that indeed the strategy that they adopted helped their enterprise to improve performance whereas seven percent of the social enterprises indicated that their performance did not improve following the adoption of a new strategy. Ten of the social enterprises felt that strategy had helped them improve performance to a great extent. Eight of the social enterprises felt that strategy helped them improve their performance to a moderate extent. Another eight felt that strategy had helped them improve their performance to a very great extent. Whereas three and two social enterprises felt that strategy had helped them improve their performance to a little extent and to no extent respectively. 
According to Thune and House (1970) organizations that plan strategically have historically out performed those that did not plan. Ansoff et al (1970) concurs that formal planning pays and it appears to assist firms to achieve success. To account for the seven percent of the social enterprises whose strategy did not improve their performance. Greenly (1986) states that the relationship between strategic planning and performance is yet to be established and that performance difference among such social enterprises would find explanations in key theoretical underpinnings among them; resource based theory, Dynamic capability theory and industrial organization economics theory. Therefore, it would be naïve to conclude that strategic planning and implementation is the sole cause of good performance in organizations. Since firms may be using other management practices that contribute to continuously improved performance. Secondly variations on strategic planning and performance improvement are best explained by methodological differences and implementation disconnect.

\section{Conclusions and Recommendations Conclusions}

Based on the results from data analysis and findings of the research, it can be concluded that the following are the popular performance improvement strategies amongst social enterprises in Kenya: planned strategy, niche market competition strategy and dominant market competition strategy. The decision criteria for social enterprise strategic orientation depend on technological as well as socioeconomic characteristics (demographic, economic, geographic, and climatic characteristics), political and legal characteristics, financial conditions and consumer variables (lifestyle, preferences, culture, taste, purchase behavior, and purchase frequency). Every social enterprise has its own strength, weakness and each market has its own opportunities and threats. None of the performance improvement strategies is suitable for all the market or even one market for a certain period. Amending strategy when changes occur in the external environment is the right means towards achieving sustained organizational performance. This study will benefit managers of Social Enterprises in Kenya when they adopt strategies that will realign with the changing business environment which will influence performances of Social Enterprise in Kenya.

The finding on the influence of strategy on social enterprise performance is that; the link between strategy and performance is elusive. It has not been possible to establish a causal relationship between strategy and organizational performance. This is because there exist a gap between strategy and performance which can be explained by; social enterprises rarely track performance against strategic goals, multi-year results rarely meet projections, a lot of value is lost in translation, inadequate resources, poor leadership or uncommitted leadership and the quality of personnel involved with strategy implementation. On the contrary, there are a range of potential advantages from strategic planning and implementation. Hence the $93 \%$ of social enterprises that felt that strategy influenced their performance. His findings have been supported by other empirical studies such as Thune and House (1970); Greenly (1986); Pearce and Robinson (1987); Miller (1994). 


\section{Recommendations for Policy and Practice}

Policy plays an important role in supporting or inhibiting social enterprise performance in Kenya. The limited number of respondents actually $44 \%$ indicates that social enterprises are few in Kenya. The government ought to create an enabling environment for impact investing through; directing large institutions to invest in target areas, providing tax credits and other subsidies for investments which are socially impactful, creating investment opportunities or by providing special recognition for special purpose enterprises. The government can strengthen the capacity of social enterprises by partnering with financial institutions to inject capital into such investments as well as giving them direct participation in government procurement.

This study revealed that the social impact enterprises in Kenya adopted competitive strategies in their policy framework in order to improve their performance. This study can therefore be used by the policy makers in these firms to enrich their strategies. The study can also be used as a point of reference for other firms in different industries to enrich their policy making decisions. The use of different mixes of strategies is an interesting phenomenon which policy makers can adopt to outwit their competition.

\section{Limitations of the Study}

This study was carried out well but there were a few limitations that were experienced during the study. One of the limitations was that the targeted response of $100 \%$ was not achieved. The response rate was $44 \%$ which was below the targeted response. The study could have been much better if the response was at the targeted $100 \%$. This is because the study could have gotten all the views of the targeted respondent.

\section{Suggestions for Further Research}

Future research on social enterprises can benefit substantially from a richer conceptualization of strategy and performance where all parties involved in organizational strategic planning and implementation are involved as respondents rather than the management only. Furthermore, research on strategy and performance is still a prime area for research. In-depth analysis of single Social impact enterprises would give room to understanding key underlying variables that may have been globally over shadowed by findings in this particular study. Social enterprises have not been studied in relation to change management.

\section{References}

Abbott, C. (1994). Performance Measurement in Library and Information Services, London: Asli.

Ansoff, I. and McDonell, E. (1990). Implanting Strategic Management, $\left(2^{\text {nd }}\right.$ Ed.), Englewood Cliffs: Prentice Hall.

Allavida. (2011). Social Investment in Kenya. Nairobi; Allavida Kenya Limited

Berelson, B. (1952). Content Analysis in Communication Research. Glencoe, III: Free Press.

Burnes, B. (2004). Managing Change. England: $4^{\text {th }}$ Edition Pearson Education Ltd.

Darko, E. and Smith, W. (2014). Social Enterprise; Constraints and Opportunities from Kenya and Vietnam. 
INTERNATIONAL JOURNAL OF ACADEMIC RESEARCH IN BUSINESS AND SOCIAL SCIENCES

Vol. 9, No. 5, May, 2019, E-ISSN: 2222-6990 ㄷ 2019 HRMARS

Defourny, J. and Nyssens, M. (2010). Conceptions of Social Enterprise and Social Entrepreneurship in Europe and the United States: Convergences and Divergences. Journal of Social Entrepreneurship, Vol.1(1):32-53 DOI:10.1080/19420670903442053URL: http://dx.doi.org/10.1080/19420670903442053.

Gathungu, N.K (2008). Employees' Perception of Strategic Change at the Kenya National Audit Office, Unpublished MBA project, School of Business, University of Nairobi, Kenya. Government of the Republic of Kenya (2007). Kenya Vision 2030: Nairobi Government Printers.

Heller, R. (1998). Managing Teams, London: Dorling Kindersley Publisher. International Monetary Fund, (2006). Annual Report of the Executive Board for the Financial Year Ended April.

Jackson, E .T. and Associates (2012). Accelerating Impact: Achievements, Challenges and What's next in Building the Impact Investing Industry? The Rockefeller Foundation, New York.

Kiliko, J. (2000). Strategic Planning within Non -Governmental Organization (NGOs) in Kenya. Unpublished MBS Research Project, School of Business; University of Nairobi, Kenya.

Kinyua, J. (2012). Factors influencing growth of social enterprise in Kenya; A Survey of Social Enterprises in Nairobi. Unpublished MSC Research project; Jomo Kenyatta University of Agriculture and Technology (JKUAT).

Kinuu, D. Maalu, J. and Aosa E (2012). Factors Influencing Change Management Process at

Tamoil Kenya Limited. Prime Journal of Business Administration and Management (BAM), 2(8): 655-622.

Lincol, Y. and Guba, E. (2000). Handbook of Qualitative Research Sage Publication Inc. Retrieved from http://www.media.mit.edu/the-sage-handbook-qualitative-research/dp/1412974178.

Mitullah, W. (1990). Government-NGO Relationship in the Context of Alternative Development Strategies in Kenya. Institute of Development Studies, University of Nairobi, Kenya.

Mugenda, A.G. and Mugenda, O.M (2003). Research methods, Quantitative and Qualitative Approaches: Nairobi ACTS Press.

Ndemo, B. (2003). Application of Individual Growth Model in Studying the Development of

Micro and Small Enterprises in Kenya. College of Humanities and Social Sciences (CHSS); University of Nairobi, Kenya.

Nderitu, N. (2004). A Survey of Strategic Responses to Threats Posed by Changing Donor Funding Patterns by Nairobi Based Children NGOs. Unpublished MBA Research Project, School of Business, University of Nairobi, Kenya.

Nganga C. (2013). Social Investment Strategies and Sustainability of Non-P r of it Organizations in Nairobi Kenya. Unpublished MBA project, School of Business, University of Nairobi, Kenya.

Nicholls, A. and Pharoah C. (2007). The landscape of Social Investment; A Holistic Topology of Opportunities and Challenges. Skoll Centre for Social Entrepreneurship Research Paper, Oxford, England: Oxford University Press.

Otieno, H. (2011). Management of Strategic Change at Kenya Commercial Bank Group, Unpublished MBA Project, School of Business, University of Nairobi. 
Pearce, J. A. and Robinson, R.B. (Jr).2003. Strategic Management: Formulation and Implementation. ( $8^{\text {th }}$ Ed), Irwin/McGraw-Hill, New York.

Republic of Kenya, (2012). Education Sector Report: 2013/14-2015/16 medium term expenditure. Sengupta, N., Sengupta R. N. and Bhattacharya M.S. (2006). Managing Change in Organizations. New Delhi: Prentice Hall of India private limited.

World Bank, (2006). The Microfinance Revolution: Sustainable Finance for the Poor. 